\title{
Neuronal intranuclear inclusion disease presenting with an MELAS-like episode in chronic polyneuropathy
}

\author{
Tasuku Ishihara, MD, Tomoko Okamoto, MD, PhD, Ken Saida, MD, Yuji Saitoh, MD, PhD, Shinji Oda, MD, \\ Terunori Sano, MD, Takuhiro Yoshida, MD, PhD, Yuki Morita, MD, Atsushi Fujita, PhD, Hiromi Fukuda, MD, \\ Noriko Miyake, MD, PhD, Takeshi Mizuguchi, MD, PhD, Yuko Saito, MD, PhD, Yoshiki Sekijima, MD, PhD, \\ Naomichi Matsumoto, MD, PhD, and Yuji Takahashi, MD, PhD
}

Neurol Genet 2020;6:e531. doi:10.1212/NXG.0000000000000531

Neuronal intranuclear inclusion disease (NIID) exhibits diverse clinical phenotypes caused by the intronic repeat expansion of NOTCH2NLC. ${ }^{1,2}$ An acute encephalopathic episode can manifest in some patients with NIID. ${ }^{3,4}$ Herein, we report an NIID patient harboring a de novo $\left\{(\mathrm{GGA})_{\mathrm{n}}(\mathrm{GGC})_{\mathrm{n}}\right\}_{\mathrm{n}}$ repeat expansion in NOTCH2NLC, who developed abrupt mitochondrial encephalomyopathy, lactic acidosis, and stroke-like (MELAS)-like episode in the 15-year course clinical diagnosed as chronic inflammatory demyelinating polyneuropathy (CIDP).

\section{Case report}

A 31-year-old woman developed slowly progressing muscle weakness and paresthesia in all extremities. Neurologic examination at 33 years of age revealed distal dominant muscle weakness with areflexia and abnormal deep sensations in all extremities without obvious cranial nerve involvement. A nerve-conduction study revealed sensorimotor polyneuropathy in all extremities (table e-1, links.lww.com/NXG/A335). Although clinical and electrophysiologic features met the diagnostic criteria for CIDP, ${ }^{5}$ she showed limited response to immunotherapy. At 45 years, she abruptly started experiencing headaches, nausea, and eventually, loss of consciousness. Neurologic examination revealed left conjugate eye deviation, neck stiffness, and left hemiparesis. Blood analysis revealed an elevated blood lactate/pyruvate molar ratio (lactate: $2.1 \mathrm{mmol} / \mathrm{L}$, pyruvate: $0.022 \mathrm{mmol} / \mathrm{L}$, molar ratio: 91, normal range $<25.8$ ). Brain MRI showed abnormal hyperintensities in the right hemisphere on diffusion-weighted images (DWIs) (figure, A) and T2weighted images (figure, B), with gadolinium enhancement not corresponding to the vascular distribution. Hyperperfusion on arterial spin labelling (figure, C), dilation of the right cerebral artery (figure, D), and elevated lactate peak on magnetic resonance spectroscopy (MRS) (figure, E) in the involved areas were also identified. She was diagnosed with MELAS and was administered IV levetiracetam, edaravone, and oral taurine. She gradually improved without residual cognitive disturbances. Neither histopathologic studies nor whole mitochondrial genome sequence analysis on muscle biopsy showed any specific findings for mitochondrial disease. At 47 years of age, a follow-up neurologic examination revealed bilateral miosis with sluggish response to light. Brain MRI revealed both gray and white matter hyperintensities on T2-weighted images corresponding to acute encephalopathic lesions (figure, F and G). However, there was no abnormal corticomedullary hyperintensity on DWI. Abdominal skin biopsy performed at 47 years of age and re-examination of the sural nerve sample at 35 years resulted in NIID diagnosis, demonstrating eosinophilic intranuclear inclusions surrounded by a halo and antiubiquitin and p62-immunoreactive intranuclear inclusions in fibroblasts, sweat gland cells (figure, $\mathrm{H}$ ),
Correspondence

Dr. Takahashi

yutakahashi@ncnp.go.jp

From the Department of Neurology (T.I., T.O., Y. Saitoh, S.O., Y.T.), National Center Hospital, National Center of Neurology and Psychiatry, Tokyo; Department of Human Genetics (K.S., A.F., H.F., N. Miyake, T.M., N. Matsumoto), Yokohama City University Graduate School of Medicine, Kanagawa; Department of Pathology and Laboratory Medicine (T.S., Y. Saito), National Center Hospital, National Center of Neurology and Psychiatry, Tokyo; Department of Neurology (T.Y.), lida Municipal Hospital, Shinshu University School of Medicine, Nagano; Department of Medicine (Neurology and Rheumatology) (Y.M., Y. Sekijima), Shinshu University School of Medicine, Nagano; and Department of Neurology and Stroke Medicine (H.F.), Yokohama City University, Japan.

Go to Neurology.org/NG for full disclosures. Funding information is provided at the end of the article. 
Figure Imaging, histopathologic, and genetic analyses of the patient
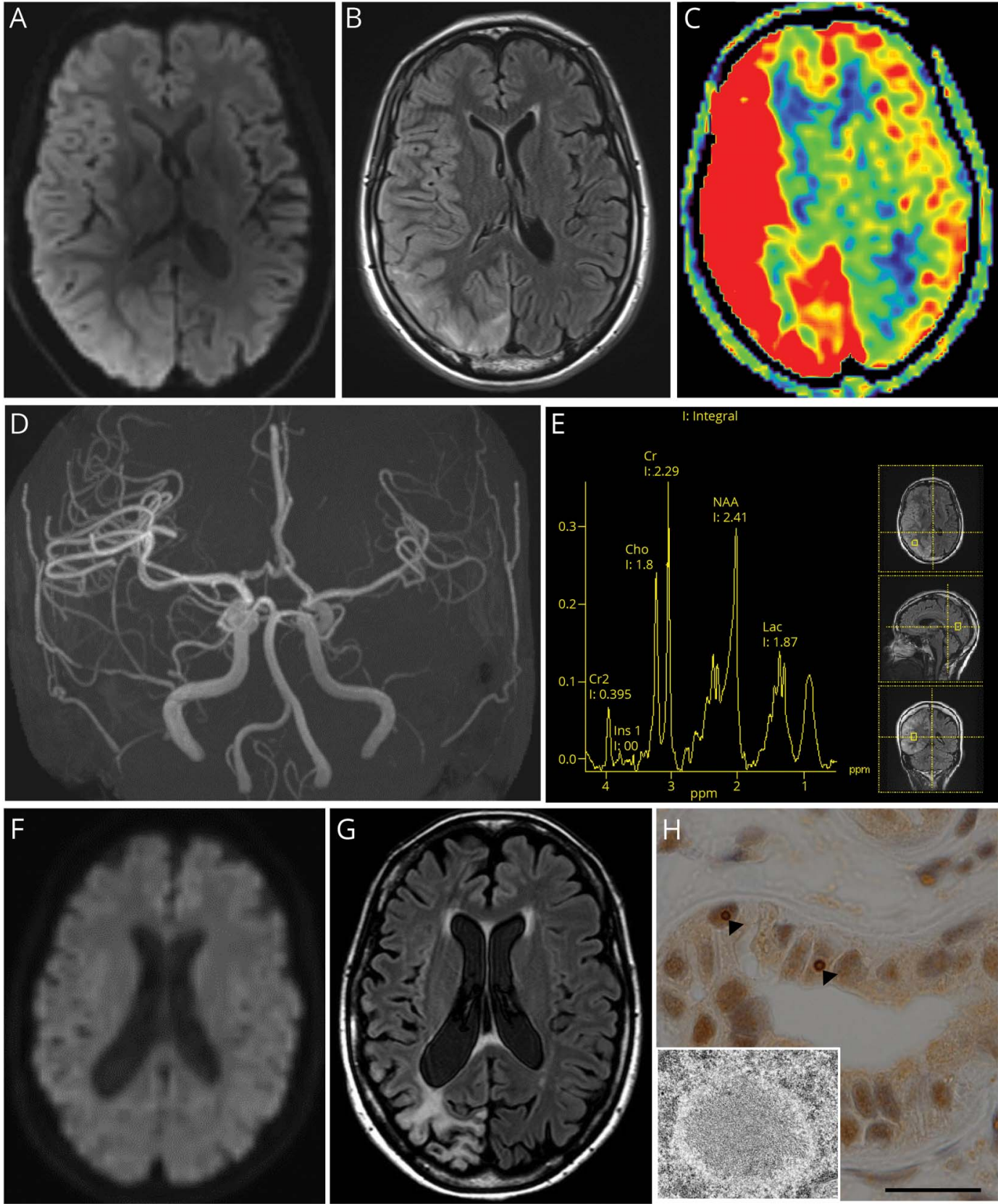

I

Patient

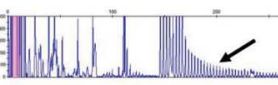

J

Patient

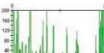

$\nabla$

Father

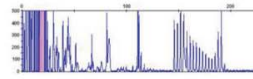

Father

Mother

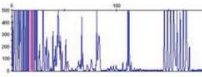

Mother

(A) DWI sequence shows hyperintensity around the right cortical and subcortical areas of parietal, temporal, and occipital lobes without corticomedullary hyperintensity. (B) FLAIR sequence shows hyperintensity and edematous areas in the right parietal, temporal, and occipital lobes. (C) ASL shows prominent hyperperfusion in accordance with the lesion. (D) MRA shows the dilation of right anterior, middle, and occipital cerebral arteries and of the right internal carotid artery. (E) MRS focused on the occipital lesion shows the lactate peak appearance. (F-G) MRI at 47 years of age (2 years after the MELAS-like episode). (F) DWI shows no corticomedullary junction DWI hyperintensity. (G) FLAIR shows leukoencephalopathy with atrophic changes in the occipital lobe. (H) Skin biopsy at the age of 47 years. Antiubiquitin positive intranuclear inclusions are seen in sweat glands (arrowheads) (scale bar $=20 \mu \mathrm{m}$ ). Electron microscopy of subcutaneous gland shows dense filamentous materials without limiting membrane (inset). (I) RP-PCR of the patient and her parents. Arrow shows a characteristic saw-tooth pattern in the patient. ()) Fluorescent repeat length analysis. GGC expansion is positive only in the patient. The expansion allele seen in the patient only is indicated as the arrowhead. ASL = arterial spin labeling; DWI = diffusion-weighted image; FLAIR = fluid-attenuated inversion recovery; MELAS = mitochondrial encephalomyopathy, lactic acidosis, and stroke; MRA = magnetic resonance angiography; MRS = magnetic resonance spectroscopy; RP-PCR = repeat-primed PCR; SPECT = single-photon emission CT. 
adipocytes, perineural cells, fibroblasts, Schwann cells, and small vessels. Triobased whole exome sequencing resulted in negative results, confirming the biological parentage using 20 rare variants (data not shown). Presence of intranuclear inclusion bodies prompted to perform mutational analysis for detecting GGC trinucleotide expansion in NOTCH2NLC. ${ }^{2}$ The trinucleotide repeat expansion was clearly visible in the patient, not in the parents, indicating a de novo mutation (figure, I and J). Long-read genomic sequencing and a cas9enrichment system revealed a heterozygous intronic (GGC) $)_{88}$ $(\mathrm{GGGA})_{1}\left\{(\mathrm{GGC})_{4}(\mathrm{GGA})_{2}\right\}_{9}(\mathrm{GGC})_{4}(\mathrm{GGA})_{1}(\mathrm{GGC})_{3}(\mathrm{GGA})_{2}$ $(\mathrm{GGC})_{2}$ repeat expansion in NOTCH2NLC. ${ }^{2}$

\section{Discussion}

We report a patient with NIID harboring a de novo intronic expansion containing $\left\{(\mathrm{GGA})_{\mathrm{n}}(\mathrm{GGC})_{\mathrm{n}}\right\}_{\mathrm{n}}$ repeats in NOTCH2NLC presenting with a MELAS-like episode in long-standing chronic polyneuropathy mimicking CIDP. The genomic mechanism underlying a de novo mutation may be associated with the existence of expansion-prone sequences or structures within or surrounding the mutation site. Elevated serum lactate/pyruvate ratio and elevated lactate peak on MRS were strongly suggestive of MELAS, although the diagnosis was genetically ruled out. To date, only one NIID case presenting with MELAS-like phenotype and suggestive pathologic mitochondrial abnormalities has been reported. ${ }^{6}$ Our case was unique in that an abnormal edematous and hyperemic brain lesion with elevated lactate peak was observed without typical corticomedullary DWI hyperintensity throughout the clinical course. Our case raised the possibility of mitochondrial dysfunction and effective therapeutic measures for mitochondrial diseases in acute encephalopathy associated with NIID.

Diverse phenotypes of NIID have been categorized into a dementia-dominant subtype typically with corticomedullary DWI hyperintense lesions and a weakness-dominant subtype predominantly with peripheral neuropathy. ${ }^{3}$ A previous longread repeat sequence analysis proposed a hypothesis that the insertion of $\left\{(\mathrm{GGA})_{\mathrm{n}}(\mathrm{GGC})_{\mathrm{n}}\right\}_{\mathrm{n}}$ repeats causes a weaknessdominant subtype. ${ }^{4}$ The complete repeat configurations in NOTCH2NLC of our case corroborated the hypothesis and supported the concept of "repeat motif-phenotype correlation."7 Further accumulation of repeat configuration data is imperative to address whether specific repeat configurations are also associated with the MELAS-like episode.

In conclusion, NIID should be considered in the differential diagnosis of chronic sensorimotor neuropathy refractory to standard therapy and MELAS-like episodes lacking the characteristic brain MRI findings of NIID. This study provides mechanistic insight into NIID pathogenesis, implying that mitochondrial dysfunction might potentially be involved in acute encephalopathy associated with NIID and repeat configurations could be a key factor determining its phenotypes.

\section{Study funding}

This work was supported by Japan Agency for Medical Research and Development (AMED) under grant numbers JP19ek0109280, JP19dm0107090, JP19ek0109301, JP19ek0109348, and JP19kk0205012 (N. Matsumoto); JSPS KAKENHI under grant numbers JP17H01539 (N. Matsumoto), and JP19H03621 (N. Miyake).

\section{Disclosure}

The authors of this study declare no conflict of interest. The description in this paper has obtained informed consent from the patient. Go to Neurology.org/NG for full disclosures.

\section{Publication history}

Received by Neurology: Genetics April 24, 2020. Accepted in final form September 1, 2020.

Appendix Authors

\begin{tabular}{|c|c|c|}
\hline Name & Location & Contribution \\
\hline $\begin{array}{l}\text { Tasuku } \\
\text { Ishihara, MD }\end{array}$ & $\begin{array}{l}\text { National Center Hospital, } \\
\text { National Center of Neurology } \\
\text { and Psychiatry (NCNP), Tokyo, } \\
\text { Japan }\end{array}$ & $\begin{array}{l}\text { Clinical analysis and } \\
\text { drafting and } \\
\text { revising the } \\
\text { manuscript }\end{array}$ \\
\hline $\begin{array}{l}\text { Tomoko } \\
\text { Okamoto, } \\
\text { MD, PhD }\end{array}$ & $\begin{array}{l}\text { National Center Hospital, NCNP, } \\
\text { Tokyo, Japan }\end{array}$ & $\begin{array}{l}\text { Clinical analysis and } \\
\text { drafting and } \\
\text { revising the } \\
\text { manuscript }\end{array}$ \\
\hline $\begin{array}{l}\text { Ken Saida, } \\
\text { MD }\end{array}$ & $\begin{array}{l}\text { Yokohama City University } \\
\text { Graduate School of Medicine, } \\
\text { Kanagawa, Japan }\end{array}$ & Genetic analysis \\
\hline $\begin{array}{l}\text { Yuji Saitoh, } \\
\text { MD, PhD }\end{array}$ & $\begin{array}{l}\text { National Center Hospital, NCNP, } \\
\text { Tokyo, Japan }\end{array}$ & $\begin{array}{l}\text { Clinical analysis and } \\
\text { drafting and } \\
\text { revising the } \\
\text { manuscript }\end{array}$ \\
\hline $\begin{array}{l}\text { Shinji Oda, } \\
\text { MD }\end{array}$ & $\begin{array}{l}\text { National Center Hospital, NCNP, } \\
\text { Tokyo, Japan }\end{array}$ & Clinical analysis \\
\hline $\begin{array}{l}\text { Terunori } \\
\text { Sano, MD }\end{array}$ & $\begin{array}{l}\text { National Center Hospital, NCNP, } \\
\text { Tokyo, Japan }\end{array}$ & Pathologic analysis \\
\hline $\begin{array}{l}\text { Takuhiro } \\
\text { Yoshida, MD, } \\
\text { PhD }\end{array}$ & $\begin{array}{l}\text { lida Municipal Hospital, Nagano, } \\
\text { Japan }\end{array}$ & Clinical analysis \\
\hline $\begin{array}{l}\text { Yuki Morita, } \\
\text { MD }\end{array}$ & $\begin{array}{l}\text { Shinshu University School of } \\
\text { Medicine, Nagano, Japan }\end{array}$ & Clinical analysis \\
\hline $\begin{array}{l}\text { Atsushi } \\
\text { Fujita, PhD }\end{array}$ & $\begin{array}{l}\text { Yokohama City University } \\
\text { Graduate School of Medicine, } \\
\text { Kanagawa, Japan }\end{array}$ & Genetic analysis \\
\hline $\begin{array}{l}\text { Hiromi } \\
\text { Fukuda, MD }\end{array}$ & $\begin{array}{l}\text { Yokohama City University } \\
\text { Graduate School of Medicine, } \\
\text { Kanagawa, Japan; Yokohama } \\
\text { City University, Kanagawa, Japan }\end{array}$ & Genetic analysis \\
\hline $\begin{array}{l}\text { Noriko } \\
\text { Miyake, MD, } \\
\text { PhD }\end{array}$ & $\begin{array}{l}\text { Yokohama City University } \\
\text { Graduate School of Medicine, } \\
\text { Kanagawa, Japan }\end{array}$ & Genetic analysis \\
\hline $\begin{array}{l}\text { Takeshi } \\
\text { Mizuguchi, } \\
\text { MD, PhD }\end{array}$ & $\begin{array}{l}\text { Yokohama City University } \\
\text { Graduate School of Medicine, } \\
\text { Kanagawa, Japan }\end{array}$ & Genetic analysis \\
\hline
\end{tabular}


Appendix (continued)

\begin{tabular}{lll}
\hline Name & Location & Contribution \\
\hline $\begin{array}{l}\text { Yuko Saito, } \\
\text { MD, PhD }\end{array}$ & $\begin{array}{l}\text { National Center } \\
\text { Hospital, NCNP, } \\
\text { Tokyo, Japan }\end{array}$ & Pathologic analysis \\
\hline $\begin{array}{l}\text { Yoshiki } \\
\text { Sekijima, MD, } \\
\text { PhD }\end{array}$ & $\begin{array}{l}\text { Shinshu University } \\
\text { School of Medicine, } \\
\text { Naomichi }\end{array}$ & Clinical analysis \\
$\begin{array}{l}\text { Matsumoto, Japan } \\
\text { MD, PhD }\end{array}$ & $\begin{array}{l}\text { Yokohama City } \\
\text { School of Medicine, }\end{array}$ & \\
\hline $\begin{array}{l}\text { Saji } \\
\text { Takahashi, } \\
\text { MD, PhD }\end{array}$ & $\begin{array}{l}\text { National Center } \\
\text { Hospital, NCNP, Tokyo, }\end{array}$ & Genetic analysis \\
\hline
\end{tabular}

\section{References}

1. Ishiura H, Shibata S, Yoshimura J, et al. Noncoding CGG repeat expansions in neuronal intranuclear inclusion disease, oculopharyngodistal myopathy and an overlapping disease. Nat Genet 2019;51:1222-1232.

2. Sone J, Mitsuhashi S, Fujita A, et al. Long-read sequencing identifies GGC repeat expansions in NOTCH2NLC associated with neuronal intranuclear inclusion disease. Nat Genet 2019;51:1215-1221.

3. Sone J, Mori K, Inagaki $\mathrm{T}$, et al. Clinicopathological features of adult-onset neuronal intranuclear inclusion disease. Brain 2016;139:3170-3186.

4. Okubo M, Doi H, Fukai R, et al. GGC repeat expansion of NOTCH2NLC in adult patients with leukoencephalopathy. Ann Neurol 2019;86:962-968.

5. Hughes RA, Bouche P, Cornblath DR, et al. European Federation of Neurological Societies/Peripheral Nerve Society guideline on management of chronic inflammatory demyelinating polyradiculoneuropathy: report of a joint task force of the European Federation of Neurological Societies and the Peripheral Nerve Society. Eur J Neurol 2006;13:326-332.

6. Morimoto S, Hatsuta H, Komiya T, Kanemaru K, Tokumaru AM, Murayama S. Simultaneous skin-nerve-muscle biopsy and abnormal mitochondrial inclusions in intranuclear hyaline inclusion body disease. J Neurol Sci 2017;372: $447-449$.

7. Ishiura H, Doi K, Mitsui J, et al. Expansions of intronic TTTCA and TTTTA repeats in benign adult familial myoclonic epilepsy. Nat Genet 2018;50:581-590. 


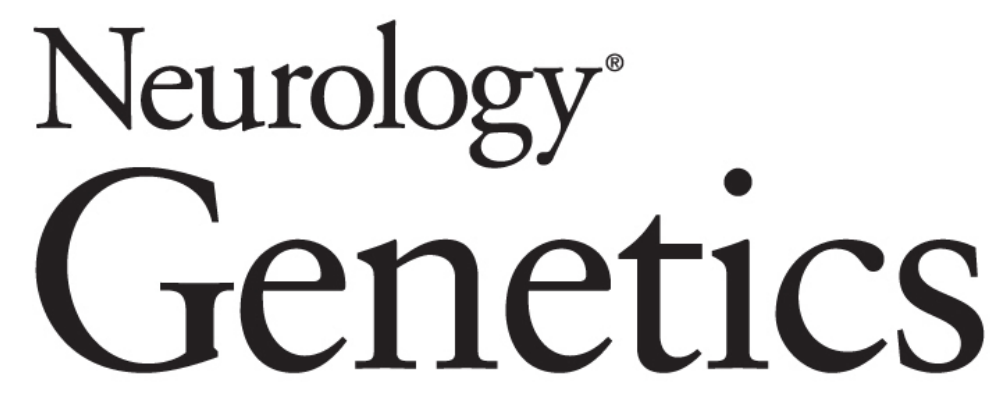

Neuronal intranuclear inclusion disease presenting with an MELAS-like episode in chronic polyneuropathy

Tasuku Ishihara, Tomoko Okamoto, Ken Saida, et al. Neurol Genet 2020;6;

DOI 10.1212/NXG.0000000000000531

This information is current as of November 19, 2020

\section{Updated Information \&} Services

References

Permissions \& Licensing

Reprints including high resolution figures, can be found at: http://ng.neurology.org/content/6/6/e531.full.html

This article cites 7 articles, 0 of which you can access for free at: http://ng.neurology.org/content/6/6/e531.full.html\#\#ref-list-1

Information about reproducing this article in parts (figures,tables) or in its entirety can be found online at:

http://ng.neurology.org/misc/about.xhtml\#permissions

Information about ordering reprints can be found online: http://ng.neurology.org/misc/addir.xhtml\#reprintsus

Neurol Genet is an official journal of the American Academy of Neurology. Published since April 2015, it is an open-access, online-only, continuous publication journal. Copyright Copyright ( 2020 The Author(s). Published by Wolters Kluwer Health, Inc. on behalf of the American Academy of Neurology.. All rights reserved. Online ISSN: 2376-7839.

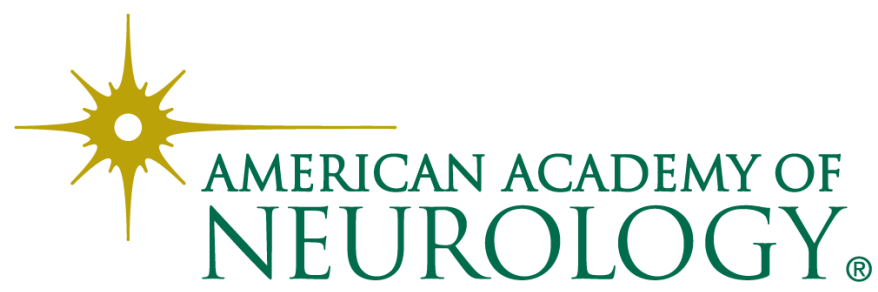

